\title{
Science in the City of London.
}

\author{
By Engr.-Capt. Edgar C. Smith, O.B.E., R.N.
}

$\mathrm{T}^{\circ}$ $O$ the student of the history of science and technology London offers a field of inquiry of wide and unfailing interest. From Westminster Abbey to the docks, from Highgate to Clapham, all routes lead to some spot with scientific associations. Ever since the Romans came, bringing with them their measuring, surveying, and surgical instruments, London has owed something to scientific inquiry, and the construction of her gates and fortifications, her historic Bridge, and her great Tower were only rendered possible through the discoveries of the ancient world. But great as is our debt to Greece and Rome, it is within modern times that science has invaded every side of human activity, and many of the most important discoveries, many of the most notable inventions, and many of the most striking applications of science have been made in London. Thus it is that from one boundary of London to the other her streets and lanes, her institutions, hospitals, and workshops, her cathedrals and churches, the river and its bridges, her parks and gardens, all have some tale to tell relating to the increase of natural knowledge.

Obvious as are the many applications of science to practical affairs to-day, and numerous as are the records of men of science who have lived and worked in London, the annals of science in the City of London still remain fragmentary and scattered. The intrinsic interest in the story was well shown by Mr. H. G. Wayling in his articles on "The Romance of Science in Bygone London ", published in Science Progress in January and April this year, and also in Dr. Charles Singer's address on "The First Century of Science in England ", given during the recent International Congress of the History of Science and Technology. The subject, too, is happily claiming the attention of the British Association, which this year for the first time is meeting in London.

"The general attitude to Nature", said Dr. Singer, "which we nowadays call scientific was opened, as far as England was concerned, by the appearance of certain works of Giordano Bruno." These works were surreptitiously printed in London in 1584, probably in the Charterhouse. Fourteen years before that, however, Henry Billingsley, Sheriff of London in 1584 and Lord Mayor in 1596, had published the first English translation of Euclid. With " a very fruitfull Præface" by Dee, Billingsley's book was printed by John Daye, dwelling over Aldersgate beneath Saint Martins. Billingsley became a knight and a member of parliament, and died in 1606. If to him we are indebted for the earliest English translation of the "Elements of Geometry", to his famous contemporary Sir Thomas Gresham we owe the establishment of Gresham College and the founding of the earliest chairs of geometry and astronomy in the country. Some science had been taught at Oxford and Cambridge long before then, but the foundation of Gresham College was one of the most important steps taken in connexion with the educational facilities of London, and with its history the story of modern science in London rightly begins.

Gresham was born about 1519 and died in 1579 . The son of a Lord Mayor, he was a servant of the State as well as a great merchant, and, during the reigns of Edward VI., Mary, and Elizabeth, acted as a sort of financial ambassador. In 1566 he founded the Royal Exchange, and, perhaps influenced by the establishment in Paris by Francis I. of the Collège Royale, now the Collège de France, he left his fine mansion in Bishopsgate to the London Corporation and the Mercers' Company for a college and endowed chairs in physic, geometry, astronomy, music, law, rhetoric, and divinity. His widow dying in 1596, the bequest then became available and the first lecturers were appointed. Briggs was chose first professor of geometry and Brerewood first professor of astronomy. To them succeeded in turn Edmund Gunter, the inventor of Gunter's chain ; Henry Gellibrand, who completed Brigg's "Trigonometria Britannica " John Greaves, the first man in modern times to measure the Pyramids ; Samuel Foster, the author of "The Use of the Quadrant" ; Rooke, declared to be " the greatest man in England for profound learning "; Walter Pope, a contributor to the first volume of the PhilosophicalTransactions; and Barrow, Wren, and Hooke. Some of these, it will be recalled, were among the founders of the Royal Society, which from its foundation in $\mathbf{1 6 6 0}$ until 1710, except for a few years after the Great Fire, met in Gresham College.

In the seventeenth century, London was also the home of Thomas Harriot, the algebraist and the first Englishman to observe sunspots; Walter Warner, Thomas Allen, Nathaniel Torporley, who is said to have acted as amanuensis to Vieta, and Dr. Wilkins, who "deserves more than any man to be esteemed the founder of the Royal Society". Many of these scientific worthies were buried in the City churches, although to-day, owing to the destruction by the Great Fire and to other causes, one may look in vain for memorials of them. Billingsley was buried in St. Katherine Coleman, Fenchurch Street; Brerewood and Hooke, like Gresham himself, in St. Helen's, Bishopsgate, " the Westminster Abbey of the City"; Gunter, Foster, and Gellibrand in St. Peter the Poor in Broad Street; Torporley in St. Alphage in London Wall; Rooke in St. Mary Outwich, Bishopsgate; Pope in St. Giles', Cripplegate; Harriot in St. Christopher le Stocks, a church which had to make way for the Bank of England; Greaves in St. Benet's, and Wilkins in St. Lawrence Jewry, of which he was one time rector. Of other old mathematicians, Thomas Digges was buried in St Mary Aldermanbury; and Collins, " the attorney-general for the mathematics ", in St.James', 
Garlick Hill. Wren, of course, lies in St. Paul's ; and Barrow in Westminster Abbey.

Bishopsgate, besides being the street in which Gresham College was situated, is the centre of a district abounding in scientific interest. In Winchester Street hard by, at his father's house, Halley, as a boy of nineteen, began his astronomical observations ; in Austin Friars, Aubert had the first of his three observatories; and at the offices of the Magnetic Company, in Old Broad Street, in 1856, the electricians, Whitehouse and Bright, showed Morse that signals could be sent at the rate of 272 a minute through 2000 miles of wire laid to and fro between London and Manchester. Latimer Clark had shown Airy and Faraday the same experiment at Lothbury in the City three years before. In Bishopsgate also stands the little church of St. Ethelburga, which has recently been enriched with three beautiful windows erected to the memory of Henry Hudson, who with his crew took Holy Communion in the church on April 19, 1607, the day before he set sail in the Hopewell, Frobisher's old ship. Then, too, Birchin Lane and Finch Lane, at the back of the Royal Exchange, remind us of the work of Newcomen and Watt. For a year, Watt worked in Finch Lane learning to make sextants, all the time going in fear of the press gang. Farther to the east, the Tower, the Mint, and Trinity House all have links with modern science; with one or the other have been connected Sir Jonas Moore, Flamsteed; Drummond, the inventor of the lime-light; Forsyth, the inventor of the fuse; Newton; Graham the chemist ; Sir John Herschel ; RobertsAusten, who was responsible for the quality of no less than $£ 150,000,000$ of gold coins; the engineers Barlow and Douglas ; and Faraday, Tyndall, and Rayleigh. The City, too, was the home of the early clock makers, map makers, and instrument makers, and some of these were associated with the old Mathematical Society of Spitalfields, of which Major P. A. MacMahon gave some particulars in his presidential address to Section A of the British Association in 1901.

This old scientific society came to an end in 1845 , but long before then the centre of London science had shifted westward. Just as the history of science in London in the seventeenth century is bound up principally with the district to the east of St. Paul's, so its history in the eighteenth century brings us to the west of St. Paul's and to Fleet Street and the Strand. St. Paul's itself, as Mr. Wayling has pointed out, Christ's Hospital, the Charterhouse, Child's Coffee House in St. Paul's Churchyard, the London Coffee House in Ludgate Hill, the Mitre Tavern in Fleet Street, and the Crown and Anchor in the Strand, all have some scientific associations, as also have the Temple and Somerset House.

Fleet Street abounds in both literary and scientific associations, and to-day the Newcomen Society frequently meets in Prince Henry's Room in a house which was familiar to Newton and his fellows who came to Crane Court in Fleet Street for the meetings of the Royal Society. On Sept. 8, 1710, Newton as president had summoned the council of the Society for the purpose of informing them that the house of the late Dr. Brown in Crane Court was to be sold, " and being in the middle of the Town, and out of noise, might be a proper place to be purchased by the Society for their Meetings ". The outcome of this suggestion was the purchase for $£ 1450$ of Dr. Brown's house and the next ; and on Nov. 8, 1710 , the Society held its first meeting in its own home, and Gresham College, much to its detriment, saw the Society no more. During the seventy years the Society met at Crane Court it had ten different presidents, among whom were Sir Hans Sloane, Martin Folkes, Sir John Pringle, and Sir Joseph Banks, the last of whom was just beginning his long period of office, when in 1780 the Society, through George III., was granted the use of apartments in Somerset House. Newton's last appearance in Crane Court was when he presided over a meeting on March 2, 1727, eighteen days before he died. To the period the Society was housed in Crane Court belong the labours of Halley, Bradley, and Hadley ; the foundation of the Copley Medal and its award to Gray, Desaguliers, Bradley, Harrison, Canton, Franklin, Dollond, Smeaton, Cavendish, Priestley, and Cook ; the promotion by the Society of the practice of inoculation; the controversy over lightning conductors, and the furtherance of expeditions to observe the transits of Venus of 1761 and 1769.

In those days several members lived quite close to Crane Court. James Ferguson, elected F.R.S. in 1763 , a very remarkable self-taught man, had his home in Bolt Court, where Johnson lived, and he died there in 1776. From Ferguson's books Herschel gained his first knowledge of astronomy. Crane Court and Bolt Court are on the north side of Fleet Street. On the other side was Water Lane, now Whitefriars Street. Tompion, the famous watchmaker, had a shop at the sign of the Dial and Three Crowns at the corner of Water Lane. Here George Graham worked for Tompion, married his niece, and succeeded to his business, which, however, he moved across Water Lane to the Dial and One Crown. Graham's house was a workshop, a laboratory, and an observatory combined. $\mathrm{He}$ and Tompion to-day rest in the same grave in the nave of Westminster Abbey. Another famous Fleet Street instrument maker was Pinchbeck, and another, Troughton, who died at No. 138. Just below Whitefriars Street is Salisbury Court, leading to St. Bride's Church and Dorset Street. Salisbury Court once contained the "workhouse " of Captain Thomas Savery, "the most prolific inventor of his day ", and there in 1702 his steam pumps could be seen.

In St. Bride's Church is the monument to Dr. Wells, bearing representations of the Rumford Medal of the Royal Society, which was awarded him for his excellent memoir on dew. The church also recalls the names of Wren and of the chemist Delaval, who described the damage done to it by lightning in 1764 . He also wrote an account of the damage to St. Paul's by lightning in 1772 . About forty years after this, at No. 53 Dorset Street, lived Mr. Tatum, in whose house the City Philosophical Society met on Wednesday evenings.

No. 3230 , VoL. 128] 
After his trip to the continent with Davy, Faraday became a member of this Society and it was in this house he served his apprenticeship as a lecturer.

Such are a few of the scientific associations of Fleet Street and its neighbourhood. Were it possible to continue the story, the survey would take us into Chancery Lane and Gunpowder Alley and to the Middle Temple, where William Ball, the first treasurer, was buried, and Garden Court, the first home of the Geological Society, and thence back into the Strand and its surroundings, and so still farther westward. For the history of science in both the City of London and greater London during the nineteenth century, the birth and growth of our great scientific and technical societies and institutions, their work and influence, as well as university education, the volume on "London and the Advancement of Science", published by the British Association, should be consulted.

Altogether apart from the records of any organisation, however, there is much of an intimate and personal character awaiting the student of science in London. In the lives of men of science, as in the lives of others, are to be found those incidents, anecdotes, and observations which are the breath of biography and by which we are able in some degree to reconstruct the past. With a knowledge of the past, London becomes a place of memories, and in imagination we can join the company of Raleigh and the Earl of Northumberland and his 'three magi' in the Tower, or visit the lecture rooms of Hauksbee and Desaguliers or stand beside Voltaire at the grave of Newton. In fancy we can endeavour to break through the strange seclusion in which Cavendish lived and worked in his house on Clapham Common, watch Davy in the laboratory overcome with delight as he sees the first globules of metallic potassium form, assist Frank Buckland in his efforts to find the coffin of John Hunter in the crypt of St. Martin's-in-the-Fields, or travel across London with Kekule on the evening he first saw the atoms linked.

This story is best told in Kekule's own words. It takes us back to 1855, when Kekulé, at the age of twenty-six, was assistant to Stenhouse at St. Bartholomew's Hospital. Living in Clapham, he was returning home from a visit to Hugo Müller at Islington. "One fine summer evening", he says, "I was returning by the last omnibus, "outside" as usual, through the deserted streets of the metropolis, which are at other times so full of life. I fell into a reverie, and lo, the atoms were gambolling before my eyes! Whenever, hitherto, these diminutive beings had appeared to me, they had always been in motion, but up to that time I had never been able to discern the nature of their motion. Now, however, I saw how frequently two smaller atoms united to form a pair; how a larger one embraced the smaller ones; how still larger ones kept hold of three or even four of the smaller; whilst the whole kept whirling in a giddy dance. I saw how the larger ones formed a chain dragging the smaller ones after them, but only at the ends of the chain. I saw what our Past Master, Kopp, my highly honoured teacher and friend, has depicted with such charm in his 'Molekularwelt'; but I saw it long before him. The cry of the conductor, 'Clapham Road', awakened me from my dreaming; but I spent a part of the night in putting on paper at least sketches of these dream forms. This was the origin of the Structurtheorie."

\section{Modern Apparatus for the Reproduction of Speech and Music.}

By Dr. N. W. McLachLan.

$\mathrm{S}^{\mathrm{o}}$ OUNDS can be divided broadly into two classes: (a) transients, with which one is mainly concerned in speech, and to a lesser extent in music; (b) continuous sounds, which pertain chiefly to instrumental music and singing. Since a transient can be represented by an infinite frequency spectrum, the ideal apparatus should be capable of reproducing the entire range from zero to infinity. Fortunately for designers, the sensitivity of the ear is limited to the range 25-20,000 cycles (according to the individual). The widest range adequately covered by a single reproducer is from 50 to 7000 cycles, but this can be extended to 12,000 cycles by an additional reproducer. The range covered by the ordinary domestic loud speaker of the moving coil variety is roughly from 40 to 5000 cycles.

The energy of speech and music is conveyed by the frequency band below 500 cycles, whilst the interpretational and intelligibility characteristics reside in the range above this. Attenuation of the lower register is accompanied by a lack of body; for example, a pedal organ sounds like a harmonium.
Attenuation of the upper register makes speech woolly, unnatural, and difficult to understand, music loses character and brilliance, whilst transients are travestied to a new type of sound; for example, the rustle of paper has never been heard over the microphone! The faithful reproduction of paper rustling and coin jingling involves frequencies greater than 10,000 cycles.

It is impossible to deal here with all forms of reproducing apparatus, but two representative types have been chosen, in both of which the driving mechanism is a circular coil immersed in a strong radial magnetic field. In the first or hornless type, the reproducing mechanism is a conical paper diaphragm $10-15 \mathrm{~cm}$. in radius, to which the coil is rigidly attached (Fig. 1). The coil is constrained to move axially by a centering device, whilst the diaphragm is supported at its periphery by an annulus of leather, rubber, or other material. This arrangement is associated with some form of baffle to prevent interference between the pressure waves on each side of the diaphragm, since they are of opposite sign. The interference increases with 